\title{
Ebola virus: Awareness about the disease and personal protective measures among junior doctors of a tertiary hospital in Delhi, India
}

\section{Shailaja Daral, Sunil Kumar Singh, Anita Khokhar}

Department of Community Medicine, Vardhman Mahavir Medical College and Safdarjung

Hospital, New Delhi, India

Address for the Correspondence: Dr. Shailaja Daral, Department of Community Medicine, Vardhman Mahavir Medical College, Vardhman Mahavir Medical College and Safdarjung Hospital, New Delhi - 110 029, India. E-mail:sd.daral@gmail.com

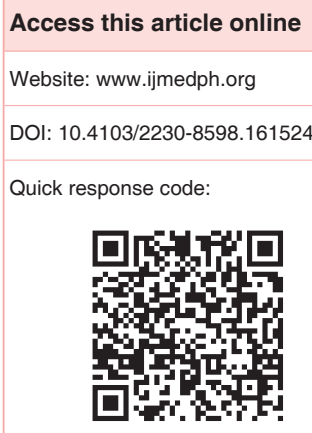

Introduction: The Ebola virus disease (EVD) outbreak in West Africa in 2014 has affected $>8$ countries in the world and claimed $>6000$ lives so far. Health professionals are at increased risk of acquiring infection while attending to patients. Aims and Objectives: The present study aimed to determine the awareness about epidemiology of and role of personal protection measures from EVD among junior doctors of a tertiary hospital in Delhi, India. Materials and Methods: A self-administered questionnaire was used to collect information from the study participants. A total of 225 out of 370 junior doctors were included in the study. Results: All the study participants had heard about EVD, but only four-fifth of them were aware of the correct route of transmission and source of infection of EVD. Only $40 \%$ of the study participants knew that reservoir of infection of EVD existed. $>80 \%$ of the study participants felt the need for quarantine and restriction on travel to affected areas for control of the spread of EVD outbreak. Only $64 \%$ of the study participants knew that presently only supportive management exists for EVD and no approved vaccine is available. Almost $90 \%$ of the study participants emphasized on the role of personal protection in the prevention of the spread of EVD. Conclusion: The knowledge of junior doctors was sub-optimal and despite the stress on universal work precautions, not all felt the need to follow them for this disease which has such a high case fatality rate.

Key words: Ebola, health care workers, outbreak, personal protection, West Africa

\section{INTRODUCTION}

Ebola virus disease (EVD), which was formerly known as Ebola hemorrhagic fever, is a severe, often fatal illness, with an average case fatality rate of $50 \%$. The genus Ebola virus belongs to the virus family Filoviridae. A total of five sub-species of Ebola virus have been identified - Zaire, Bundibugyo, Sudan, Reston, and Tai Forest. The EVD affects humans and nonhuman primates. The disease was first identified in 1976 when two outbreaks occurred simultaneously, one in the village Yambuku near the Ebola River in the Democratic Republic of Congo and the other in the remote area Nzara in Sudan. ${ }^{[1]}$

The current outbreak of EVD has occurred in West Africa and till date, has affected eight countries namely Guinea, Sierra Leone, Liberia, Nigeria, Senegal, Mali and United States of America, and Spain. ${ }^{[2]}$ The World Health Organization (WHO) also confirmed another outbreak of EVD in the Democratic Republic of Congo in August 2014 which is genetically unrelated to the main epidemic. ${ }^{[3]}$ The virus causing the current outbreak belongs to Zaire sub-species. The first case was notified from Guinea in March 2014. $\cdot^{[1]}$ As on December 3, 2014, a total of 17,145 confirmed, probable and suspected cases have been reported and 6070 deaths have been reported, with a case fatality rate of almost $60 \%$ in the confirmed cases. ${ }^{[2]}$ Liberia, Sierra Leone, and Guinea are the worst affected nations. ${ }^{[2]}$ Moreover, this is the most severe outbreak of EVD since its discovery in 1976. The outbreaks of EVD in Senegal, Nigeria, and Spain were declared over on October 17, 19 October, and December 2, 2014, respectively. ${ }^{[4]}$ On August 8, 2014, the Director General of WHO declared the current EVD outbreak as a "Public Health Emergency of International Concern." [1] The WHO warns against the risk of Ebola virus becoming endemic in West Africa, and hence burdening and deteriorating the already poor and scarce health care network of West Africa. ${ }^{[5]}$ 
Most of the cases of EVD occurred in people of economically reproductive age group (15-44 years old) and equally affected both males and females. The most common symptoms to be reported by the patients are fever, fatigue, and vomiting, with hemorrhagic symptoms reported from only a minority of cases. ${ }^{[1]}$

The EVD is an occupational hazard too. The health care workers and laboratory workers are at a heightened risk of acquiring Ebola virus while attending to cases of EVD and their samples, respectively. The WHO instructs that samples from patients are an extreme biohazard risk and hence laboratory testing on the same should be done under maximum safety conditions. Allaranga et al. had previously shown that almost one-tenth of all cases of EVD in Africa occurred in health care workers. ${ }^{[6]}$ Nkoghe $e t$ al. had also concluded that increased awareness and rapid response by healthcare system contributes to early interruption of EVD spread. ${ }^{[7]}$ In the current outbreak too, the WHO reported that by October 27, 2014, a total of 521 health care workers have acquired EVD and 272 have died. ${ }^{[8]}$ The major factors contributing to this problem in health care workers are their relative inexperience in dealing with the disease and also lack of resources for personal protection.

The Ebola virus outbreak 2014 has led to the isolation of West Africa, lockdown of societies and massive disruption of health facilities and economies in this part of the world. The problem is already being expected to worsen, with the WHO predicting the number of cases to double almost every month. ${ }^{[5]}$

Current understanding of Ebola virus points to the fruit bats of Pteropodidae family as its natural hosts. Since India comes under the home range of Pteropodidae family of fruit bats, there is a potential risk of Indian population being affected with the virus and its disease. ${ }^{[9]}$ The Ministry of Health and Family Welfare (MOHFW), Government of India (GOI) recognizes the risk and hence started a telephone helpline to improve awareness and dispel fears of the population. ${ }^{[10]}$ There are no studies concerning preparedness on EVD outbreak in India. The aim of the present study was to assess the knowledge of junior doctors of a tertiary hospital in Delhi about the EVD and personal protection regarding the same. The junior doctors are a crucial part of the health system and are usually the first to encounter and attend to patients when they present in the hospital.

\section{MATERIAL AND METHODS}

A cross-sectional study was carried out by the Department of Community Medicine, Vardhman Mahavir Medical College and Safdarjung Hospital, New Delhi, India. Safdarjung Hospital is a tertiary hospital with an out-patient attendance of close to 10,000/day. There are approximately 1000 doctors, including 370 junior doctors which provide health care services to the patients seeking healthcare in this hospital. Junior doctors include medical graduates undergoing 1-year compulsory rotatory internship in the hospital, and also nonacademic junior resident doctors working in the hospital.
All the junior doctors who were available on duty during the period of data collection in their respective ward, out-patient department or OT, were included in the study. This way, a total of 225 out of 370 junior doctors participated in the study.

Permission for conducting the study was taken from the Medical Superintendent of the hospital. Data was collected over a fortnight, between $1^{\text {st }}$ September and $15^{\text {th }}$ September 2014. Written informed consent was taken from all the study participants. A selfadministered, pretested, semi-structured, and printed questionnaire in the English language was given to the study participants, and it consisted of a total of 20 questions on the knowledge, attitude, and practices of study participants related to the EVD. Confidentiality of the study participants was ensured and the data collected were used only for academic purposes. All the data were analyzed using licensed SPSS Version 21 (Chicago, Illinois, USA).

\section{RESULTS}

A total of 225 out of 370 junior doctors participated in the study. Thus, the overall response rate was $94 \%$. Two-third of the study participants were graduates doing internship while the rest were nonacademic junior resident doctors.

All the study participants had heard about EVD, and the most common $(157 ; 70 \%)$ source of information was mass media (television and internet). The awareness about the recent EVD outbreak was seen in $204(90.7 \%)$ of the study participants, but only 169 of these $204(82.8 \%)$ correctly knew about the place of this outbreak, that is, West Africa [Table 1].

Only $187(83.1 \%)$ and $174(77.3 \%)$ of the total study participants knew about the correct route of transmission (animal to human) and source of infection (body fluids and secretions) of Ebola virus, respectively. Furthermore, while two-third (152; 67.5\%) of the study participants knew that reservoir of Ebola virus exist, $<60 \%$ of these correctly identified fruit bats as the reservoir [Table 1].

Almost four-fifth $(178 ; 79.1 \%)$ of the study participants identified health care workers to be at the greatest risk of acquiring Ebola virus, followed by families of affected people (145; 64.4\%), handlers of corpses $(106 ; 47.1 \%)$, and tourists to affected regions (91; 40.4\%).

The majority of study participants had knowledge about the various symptoms and signs of EVD. The most commonly known clinical features were sudden onset fever $(192 ; 85.3 \%)$ followed by intense weakness $(164 ; 72.9 \%)$ and headache $(157 ; 69.8 \%)$ [Table 2]. Only $129(57.3 \%)$ of the total study participants correctly knew the incubation period of EVD (21 days).

While $84 \%$ (189) of the study participants felt that quarantine does play a role in EVD outbreak containment, only 129 (68.3\%) of these correctly knew about the duration for which quarantine is recommended. The most commonly identified places of quarantine were ports, followed by hospitals and schools. A total of $163(72.4 \%)$ study participants knew that EVD can be transmitted even after 


\begin{tabular}{|c|c|}
\hline Knowledge about EVD & Number (\%) \\
\hline \multicolumn{2}{|l|}{ Source of information $(n=225)$} \\
\hline Mass media & $168(74.7)$ \\
\hline Other people & $36(16.0)$ \\
\hline Medical literature & $21(09.3)$ \\
\hline \multicolumn{2}{|c|}{ Current status in the world $(n=225)$} \\
\hline Outbreak in 2014 & $204(90.7)$ \\
\hline No recent outbreak & $21(09.3)$ \\
\hline \multicolumn{2}{|c|}{ Place of recent outbreak $(n=204)$} \\
\hline West Africa & $169(82.8)$ \\
\hline South America & $18(08.9)$ \\
\hline Asia & $10(04.9)$ \\
\hline North America & $07(03.4)$ \\
\hline \multicolumn{2}{|c|}{ Route of transmission $(n=225)^{*}$} \\
\hline Animal to human & $187(83.1)$ \\
\hline Human to human & $48(21.3)$ \\
\hline Animal to animal & $30(13.3)$ \\
\hline Human to animal & $29(12.9)$ \\
\hline Vector-borne & $12(05.3)$ \\
\hline \multicolumn{2}{|l|}{ Source of infection $(n=225)^{*}$} \\
\hline Body fluid and secretions & $174(77.3)$ \\
\hline Air droplets & $93(41.3)$ \\
\hline Water & $21(09.3)$ \\
\hline Food & $13(05.8)$ \\
\hline Mosquito bite & $12(05.3)$ \\
\hline Don't know & $04(01.8)$ \\
\hline \multicolumn{2}{|c|}{ Existence of reservoir of infection $(n=225)$} \\
\hline Yes & $152(67.5)$ \\
\hline No & $38(16.9)$ \\
\hline Don't know & $35(15.6)$ \\
\hline \multicolumn{2}{|c|}{ Reservoir of infection $(n=152)^{*}$} \\
\hline Fruit bats & $90(59.2)$ \\
\hline Pigs & $31(20.4)$ \\
\hline Cattle & $29(19.1)$ \\
\hline Vegetation/soil & $27(17.8)$ \\
\hline Mosquito & $12(07.9)$ \\
\hline No response & $05(03.3)$ \\
\hline \multicolumn{2}{|l|}{ Incubation period $(n=225)$} \\
\hline 0-7 days & $71(31.6)$ \\
\hline 2-21 days & $129(57.3)$ \\
\hline 1-2 months & $10(04.4)$ \\
\hline Don't know & $15(06.7)$ \\
\hline
\end{tabular}

*Multiple responses. EVD = Ebola virus disease

recovery of the patient, but only half of these (82; 50.3\%) identified the correct duration of infectivity (42 days or 6 weeks). Most (203; $90.2 \%$ ) of the study participants knew that it is unsafe to travel to a place of EVD outbreak [Table 3].

Knowledge about treatment of EVD was found to be poor. A total of $164(72.9 \%)$ of the study participants correctly knew that currently there is only supportive management for EVD. Another $32(14.2 \%)$ answered that there is an approved vaccine available for the disease (which is incorrect as vaccines for Ebola are currently in different phases of trial). In case of suspicion of EVD in a person,

\begin{tabular}{lc} 
Table 2: Distribution of study participants \\
according to their knowledge about the clinical \\
presentation in EVD $(\boldsymbol{n}=\mathbf{2 2 5})$ \\
\hline Clinical features of EVD & Number $(\%)^{*}$ \\
\hline Sudden onset fever & $192(85.3)$ \\
Fatigue & $164(72.9)$ \\
Headache & $157(69.8)$ \\
Bleeding episodes & $155(68.9)$ \\
Myalgia & $148(65.8)$ \\
Arthralgia & $105(46.7)$ \\
Diarrhea & $103(45.8)$ \\
Seizures & $26(11.6)$ \\
Constipation & $17(07.6)$ \\
Cough & $15(06.7)$ \\
Blindness & $14(06.2)$ \\
Edema & $14(06.2)$ \\
Cyanosis & $10(04.4)$ \\
No response & $03(01.3)$ \\
\hline *Multiple responses. EVD = Ebola virus disease
\end{tabular}

$156(69.3 \%)$ of the study participants felt the need for immediate medical care and advice, while $143(63.5 \%)$ felt that surveillance agencies should be informed [Table 3].

Among the study participants, 201 (89.3\%) correctly recommended use of personal protective measures by health care workers to prevent the spread of Ebola virus. Of these, 165 (82.9\%) felt the need for hand hygiene, $176(87.5 \%)$ for personal protective equipment and 119 (59.2\%) for proper handling of sharps and needles. Among all those who recommended the use of personal protective equipment, gloves were considered most important universally $(176 ; 100 \%)$ while only close to one-half stressed upon use of shoe covers and goggles [Table 4].

Of all the study participants, only 105 (46.7\%) correctly knew that Dr. Ram Manohar Lohia Hospital, Delhi is the nodal center in the state for case management while only $20(08.9 \%)$ correctly knew that the National Centre for Disease Control, Delhi is the nodal center for case reporting, testing, and disease surveillance. None of the study participants knew about the existence of helpline numbers for awareness and support for EVD.

\section{DISCUSSION}

All the study participants had heard of the EVD and about $90 \%$ of them knew about the recent outbreak of the disease in the world and but out of these only $75 \%$ were aware of the actual place of outbreak, that is, West Africa. Almost four-fifth of the study participants were aware of the correct route of transmission and source of infection of EVD, but the awareness about the reservoir of infection was only about $40 \%$. $>80 \%$ of the study participants felt the need for quarantine and restriction on travel to affected areas for control of the spread of EVD outbreak. Only $64 \%$ of the study participants knew that presently only supportive management exists for EVD and no approved vaccine is available. Almost $90 \%$ of the study participants emphasized 


\begin{tabular}{|c|c|}
\hline Control measures in EVD outbreak & Number (\%) \\
\hline \multicolumn{2}{|l|}{ Role of quarantine $(n=225)$} \\
\hline Yes & $189(84.0)$ \\
\hline No & $25(11.1)$ \\
\hline Don't know & $11(04.9)$ \\
\hline \multicolumn{2}{|l|}{ Duration of quarantine $(n=189)$} \\
\hline 1-week & $17(08.9)$ \\
\hline 3 weeks & $129(68.3)$ \\
\hline 6 weeks & $37(19.6)$ \\
\hline No response & $06(03.2)$ \\
\hline \multicolumn{2}{|l|}{ Places where need for quarantine $(n=189)^{*}$} \\
\hline Ports & $184(97.4)$ \\
\hline Hospitals & $95(50.3)$ \\
\hline Schools & $36(19.0)$ \\
\hline \multicolumn{2}{|l|}{ Role of isolation postrecovery $(n=225)$} \\
\hline Yes & $163(72.4)$ \\
\hline No & $49(21.8)$ \\
\hline Don't know & $13(05.8)$ \\
\hline \multicolumn{2}{|l|}{ Duration of isolation postrecovery $(n=163)$} \\
\hline 1-week & $25(15.3)$ \\
\hline 3 weeks & $56(34.4)$ \\
\hline 6 weeks & $82(50.3)$ \\
\hline \multicolumn{2}{|l|}{$\begin{array}{l}\text { Role of travel restrictions to place of outbreak } \\
(n=225)\end{array}$} \\
\hline Yes & $203(90.3)$ \\
\hline No & $21(09.3)$ \\
\hline Don't know & $01(00.4)$ \\
\hline \multicolumn{2}{|l|}{ Measures for control of outbreak $(n=225)^{*}$} \\
\hline Isolation and quarantine & $178(79.1)$ \\
\hline Prompt case management & $160(71.1)$ \\
\hline Proper handling and disposal of dead bodies & $156(69.3)$ \\
\hline Mass vaccination & $27(12.0)$ \\
\hline Mosquito control & $12(05.3)$ \\
\hline No response & $06(02.6)$ \\
\hline \multicolumn{2}{|l|}{ Case management strategies available $(n=225)$} \\
\hline Supportive treatment & $164(72.9)$ \\
\hline Approved vaccine & $32(14.2)$ \\
\hline Immunoglobulin & $23(10.2)$ \\
\hline No response & $06(02.7)$ \\
\hline \multicolumn{2}{|l|}{$\begin{array}{l}\text { Action in case of suspicion of EVD in a person } \\
(n=225)^{*}\end{array}$} \\
\hline Immediate medical care and advice & $156(69.3)$ \\
\hline Notification to surveillance agency & $143(63.5)$ \\
\hline Rest at home & $62(27.5)$ \\
\hline Vaccination and no change in routine activity & $32(14.2)$ \\
\hline Don't know & $03(01.3)$ \\
\hline
\end{tabular}

*Multiple responses. EVD = Ebola virus disease

on the role of personal protection in the prevention of the spread of EVD.

There is a paucity of literature to compare the results of the present study. There were no studies to compare the findings of the present study regarding awareness about and personal protection from EVD in health care providers, though Nkoghe $e t$ al. in his study in Africa

\begin{tabular}{lc} 
Table 4: Distribution of study participants \\
according to their knowledge about personal \\
protection measures in health care workers for \\
EVD $(\boldsymbol{n}=225)$ & \\
\hline Knowledge about personal protection & \\
\hline Role of personal protection in health care & \\
workers ( $n=225)$ & $201(89.3)$ \\
Yes & $24(10.7)$ \\
No & \\
Personal protective measures in health care & \\
workers $(n=201)^{*}$ & $165(82.0)$ \\
Hand hygiene & $176(87.5)$ \\
Personal protective equipment & $119(59.2)$ \\
Proper handling of sharps and needles & \\
Personal protective equipment recommended & $176(100.0)$ \\
( $n=176)^{*}$ & $114(64.7)$ \\
Gloves & $107(60.7)$ \\
Impermeable gown & $94(53.4)$ \\
Face mask & $87(49.4)$ \\
\hline Goggles & \\
Shoe covers &
\end{tabular}

*Multiple responses. EVD $=$ Ebola virus disease

did show that increased awareness helped in early interruption of spread of EVD. ${ }^{[7]}$ The knowledge among health care providers about the importance of personal protection from Ebola virus in the present study is comparable to that seen in other infectious diseases such as HIV ${ }^{[11]}$ and swine flu. ${ }^{[12]}$

The study had some limitations. The study was restricted to only junior doctors and senior doctors and nursing staff were not included. Complete enumeration of junior doctors could also not be done due to restraints of resources. Moreover, since data were collected using a self-report questionnaire, over or under reporting could have been a problem. The results of the present study though may be generalizable among junior doctors of other tertiary hospitals in India as well because of similar standards of teaching and patient care across the country.

The present study highlights the need for awareness campaigns about EVD. The knowledge of junior doctors was sub-optimal and despite the stress on universal work precautions, not all felt the need to follow them for this disease which has such a high case fatality rate. Since junior doctors are the first contact to patients availing health care in tertiary hospitals, it is imperative to sensitize them to the clinical features of EVD so that they can institute proper personal protective measures for their own safety and also for the safety of other patients. Furthermore, none of the study participants knew about Ebola helpline number of the MOHFW, GOI, probably because the number is not simple or "catchy," and hence not easy to remember like the other helpline numbers of police, fire, and ambulance services. There is need to have easy access to knowledge about and personal protection from EVD, which can be achieved by CMEs, seminars, displays, availability of personal protective equipment and strict implementation of institutional guidelines on universal precautions. 
Daral, et al:: Awareness about and protection from ebola virus disease in junior doctors in India

\section{ACKNOWLEDGMENT}

Dr. Abha Mangal, Senior Resident, Department of Community Medicine, VMMC and Safdarjung Hospital, New Delhi for proofreading and manuscript editing.

\section{REFERENCES}

1. World Health Organization. WHO Factsheet: Ebola Virus Disease. Geneva: WHO; 2014. Available from: http://www.who.int/mediacentre/ factsheets/fs103/en/. [Last accessed on 2014 Oct 31].

2. World Health Organization. Ebola Virus Roadmap: Situation Report. Geneva: WHO; 2014. Available from: http://www.apps.who.int/iris/ bitstream/10665/137376/1/roadmapsitrep_03december2014_eng.pdf. [Last accessed on 2014 Oct 31].

3. World Health Organization. Virological Analysis: no Link Between Ebola Outbreaks in West Africa and Democratic Republic of Congo. Geneva: WHO; 2014. Available from: http://www.who.int/mediacentre/news/ ebola/2-september-2014/en/ [Last accessed on 2014 Sep 11].

4. Centers for Disease Control and Prevention. Ebola Outbreak in West Africa - Case Counts. United States of America, Atlanta: CDC; 2014. Available from: http://www.cdc.gov/vhf/ebola/outbreaks/2014-west-africa/ case-counts.html. [Last accessed on 2014 Dec 04].

5. World Health Organization. Global Alert and Response. Ebola in West Africa: Heading for Catastrophe? Geneva: WHO. Available from: http://www.who.int/csr/disease/ebola/ebola-6-months/west-africa/en/. [Last accessed on 2014 Oct 31].

6. Allaranga $\mathrm{Y}$, Kone ML, Formenty $\mathrm{P}$, Libama F, Boumandouki P, Woodfill CJ, et al. Lessons learned during active epidemiological surveillance of Ebola and Marburg viral hemorrhagic fever epidemics in Africa. East Afr J Public Health 2010;7:30-6.

7. Nkoghe D, Kone ML, Yada A, Leroy E. A limited outbreak of Ebola haemorrhagic fever in Etoumbi, Republic of Congo, 2005. Trans R Soc Trop Med Hyg 2011;105:466-72

8. World Health Organization. Ebola Virus Roadmap: Situation Report. Geneva: WHO; 2014. Available from: http://www.apps.who.int/iris/ bitstream/10665/137376/1/roadmapsitrep_290ct2014_eng.pdf. [Last accessed on 2014 Oct 31].

9. World Health Organization. Global Alert and Response. Map by Public Health Information and Geographical Information System. Available from: http://www.reliefweb.int/sites/reliefweb.int/files/resources/ A740C908AAC0FC52C12575AC00441950-map.pdf. [Last accessed on 2014 Oct 31].

10. World Health Organization. South-East Asian Region Office. India Update on Ebola Virus Disease. Available from: http://www.searo.who.int/india/ areas/communicable_diseases/india_ebola/en/. [Last accessed on 2014 Oct 31].

11. Mukherjee S, Bhattacharyya A, Sarkar BS, Goswami DN, Ghosh S, Samanta A. Knowledge and practice of standard precautions and awareness regarding post-exposure prophylaxis for HIV among interns of a Medical College in West Bengal, India. Oman Med J 2013;28:141-5

12. Datta SS, Kuppuraman D, Boratne AV, Abraham SB, Singh Z. Knowledge, attitude and practices regarding swine flu among para-medical workers in a tertiary care hospital in Pondicherry. J Commun Dis 2011;43:1-9.

How to cite this article: Daral S, Singh SK, Khokhar A. Ebola virus: Awareness about the disease and personal protective measures among junior doctors of a tertiary hospital in Delhi, India Int J Med Public Health 2015;5:217-21.

Source of Support: Vardhman Mahavir Medical College and Safdarjung Hospital, New Delhi, India, Conflicts of Interest: None declared. 